\title{
Petrologic and Mineral Physics Database for Use with the U.S. Geological Survey National Crustal Model
}

Open-File Report 2019-1035 



\section{Petrologic and Mineral Physics Database for Use with the U.S. Geological Survey National Crustal Model}

By Theron Sowers and Oliver S. Boyd

Open-File Report 2019-1035 


\title{
U.S. Department of the Interior \\ DAVID BERNHARDT, Secretary
}

\author{
U.S. Geological Survey \\ James F. Reilly II, Director
}

U.S. Geological Survey, Reston, Virginia: 2019

For more information on the USGS - the Federal source for science about the Earth, its natural and living resources, natural hazards, and the environment-visit https://www.usgs.gov or call 1-888-ASK-USGS.

For an overview of USGS information products, including maps, imagery, and publications,

visit https://store.usgs.gov.

Any use of trade, firm, or product names is for descriptive purposes only and does not imply endorsement by the U.S. Government.

Although this information product, for the most part, is in the public domain, it also may contain copyrighted materials as noted in the text. Permission to reproduce copyrighted items must be secured from the copyright owner.

Suggested citation:

Sowers, T., and Boyd, O.S., 2019, Petrologic and mineral physics database for use with the U.S. Geological Survey National Crustal Model: U.S. Geological Survey Open-File Report 2019-1035, 17 p.,

https://doi.org/10.3033/ofr20191035.

ISSN 2331-1258 (online) 


\section{Acknowledgments}

We are grateful to past and present members of the National Crustal Model advisory committee-Mike Blanpied, Sue Hoover, Will Levandowski, David Lidke, Nico Luco, Chuck Mueller, Mark Petersen, Sanaz Rezaeian, Eric Thompson, and Rob Williams, all presently or formerly at the U.S. Geological Survey-and the National Seismic Hazard Mapping Steering Committee. Special thanks to Dr. Rolf Norgaard, Megan Brown, and Phil Orlandini from the University of Colorado at Boulder, and Dr. Amy Wagner from California State University, Sacramento, for their help with edits. Bradley Hacker from the University of California at Santa Barbara, Charles Stern from the University of Colorado at Boulder, and Morgan Moschetti of the U.S. Geological Survey provided helpful and insightful reviews that improved the content of this report. This material is partially based upon work supported by the National Science Foundation under Grant No. 1261833 as well as funding by the U.S. Geological Survey Earthquake Hazards Program.

\section{Contents}

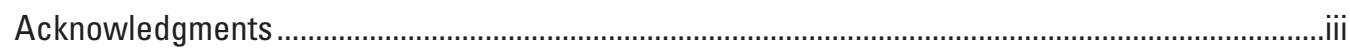

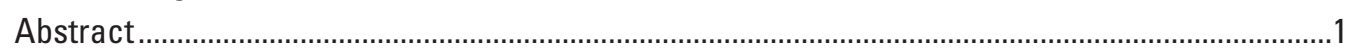

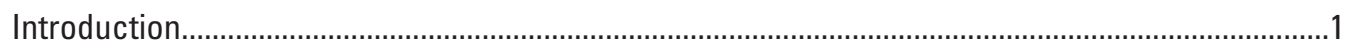

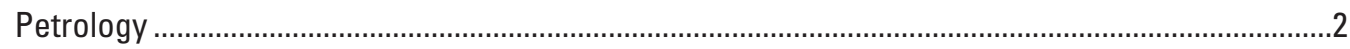

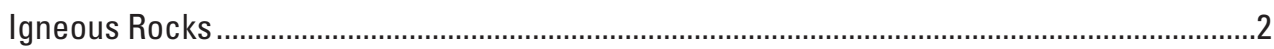

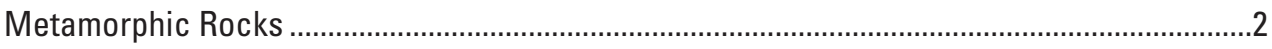

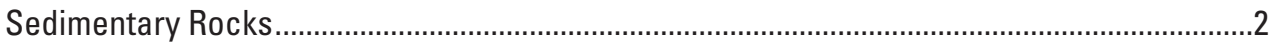

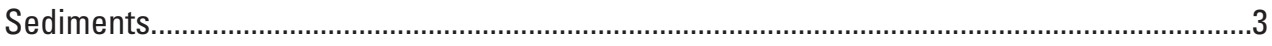

Limited Geographic Definition ........................................................................................

Broad Geographic Definition ............................................................................................

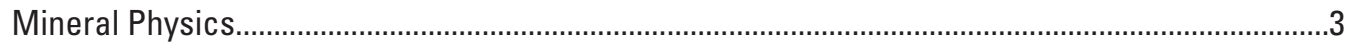

Mineral and Rock Seismic Velocity and Density.....................................................................

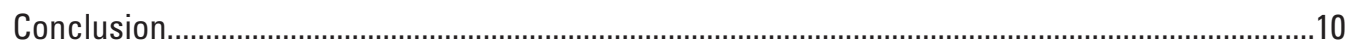

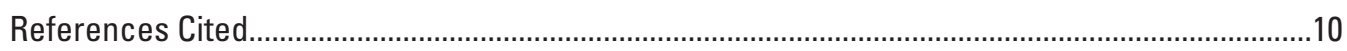

Appendix 1. Methods for Calculating Mineral Assemblages for Plutonic Igneous Rocks ..........14 


\section{Figures}

1. S-wave velocity $\left(V_{s}\right)$ and density versus $\mathrm{P}$-wave velocity $\left(V_{\mathrm{p}}\right)$ for each mineral in the National Crustal Model (NCM) ScienceBase mineral physics database that supports this report at standard temperature and pressure..

2. Combined temperature and pressure dependence of minerals in the National Crustal Model (NCM) ScienceBase mineral physics database that supports this report......

3. S-wave velocity $\left(V_{S}\right)$ and density versus $P$-wave velocity $\left(V_{p}\right)$ for each rock type in the ScienceBase petrology database that supports this report at standard temperature and pressure with no porosity or anelasticity

4. Estimates of P-wave velocity $\left(V_{\mathrm{p}}\right), \mathrm{S}$-wave velocity $\left(V_{\mathrm{S}}\right), V_{\mathrm{p}} / V_{\mathrm{S}^{\prime}}$ and $\rho$ versus depth for several well-represented upper crustal rock types ......................................................

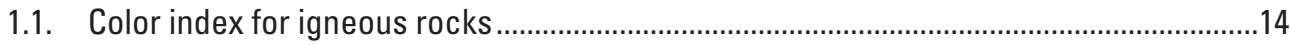

1.2. Top half of quartz-alkali feldspar-plagioclase-feldspathoid (QAPF) diagram with grid underlay to determine percentages

1.3. Adaptation of Bowen's Reaction Series in subalkaline rocks with approximate percent quartz overlay.

\section{Tables}

1. General compositions of terrigenous and evaporite sediments. Relative abundance of minerals in the sedimentary rocks, adapted from Folk (1980)

2. The 13 minerals added to Albers and Hacker (2016) updated database referred to here as HA16. Footnotes in bold are methods for parameter estimation implemented in the original HA16 database. All values are at standard temperature and pressure

1.1. Common mafic minerals in igneous rocks based on percent quartz ............................17 


\section{Conversion Factors}

International System of Units to U.S. customary units

\begin{tabular}{lll}
\hline \multicolumn{1}{c}{ Multiply } & By & \multicolumn{1}{c}{ To obtain } \\
\hline millimeter $(\mathrm{mm})$ & Length & \\
meter $(\mathrm{m})$ & 0.03937 & inch (in.) \\
kilometer $(\mathrm{km})$ & 3.281 & foot $(\mathrm{ft})$ \\
\hline \multicolumn{3}{l}{ mile $(\mathrm{mi})$} \\
\hline square meter $\left(\mathrm{m}^{2}\right)$ & 0.6214 & \\
\hline & Area & square foot $\left(\mathrm{ft}^{2}\right)$ \\
\hline cubic meter $\left(\mathrm{m}^{3}\right)$ & 10.76 & \\
\hline & Volume & cubic foot $\left(\mathrm{ft}^{3}\right)$ \\
\hline kilogram $(\mathrm{kg})$ & 35.31 & \\
\hline & Mass & pound avoirdupois $(\mathrm{lb})$ \\
\hline kilogram per cubic meter $\left(\mathrm{kg} / \mathrm{m}^{3}\right)$ & 2.205 & \\
\hline & Density & pound per cubic foot $\left(\mathrm{lb} / \mathrm{ft}^{3}\right)$ \\
\hline watt & 0.06242 & \\
milliwatt $(\mathrm{mW})$ & Energy & joule per second $(\mathrm{J} / \mathrm{s})$ \\
\hline
\end{tabular}

Temperature in degrees Celsius $\left({ }^{\circ} \mathrm{C}\right)$ may be converted to degrees Fahrenheit $\left({ }^{\circ} \mathrm{F}\right)$ as

$$
{ }^{\circ} \mathrm{F}=\left(1.8 \times{ }^{\circ} \mathrm{C}\right)+32 \text {. }
$$

Temperature in degrees Fahrenheit $\left({ }^{\circ} \mathrm{F}\right)$ may be converted to degrees Celsius $\left({ }^{\circ} \mathrm{C}\right)$ as

$$
{ }^{\circ} \mathrm{C}=\left({ }^{\circ} \mathrm{F}-32\right) / 1.8 .
$$

Temperature in degrees Kelvin $\left({ }^{\circ} \mathrm{K}\right)$ may be converted to degrees Celsius $\left({ }^{\circ} \mathrm{C}\right)$ as

$$
{ }^{\circ} \mathrm{K}={ }^{\circ} \mathrm{C}+273.15
$$

\section{Abbreviations}

$\begin{array}{ll}\text { GMM } & \text { Ground motion model } \\ \text { IUGS } & \text { International Union of Geological Sciences } \\ \text { NCM } & \text { National Crustal Model } \\ \text { NSHM } & \text { National Seismic Hazard Map } \\ \text { OAPF } & \text { quartz-alkali feldspar-plagioclase feldspar } \\ \text { STP } & \text { Standard temperature and pressure } \\ \text { USGS } & \text { U.S. Geological Survey } \\ V_{P} & \text { P-wave velocity } \\ V_{S} & \text { S-wave velocity }\end{array}$





\title{
Petrologic and Mineral Physics Database for Use with the U.S. Geological Survey National Crustal Model
}

\author{
By Theron Sowers, ${ }^{1}$ and Oliver S. Boyd ${ }^{2}$
}

\section{Abstract}

We present a petrologic and mineral physics database as part of the U.S. Geological Survey National Crustal Model (NCM). Each of 209 geologic units, 134 of which are currently part of the geologic framework within the NCM, was assigned a mineralogical composition according to generalized classifications with some refinement for specific geologic formations. This report is concerned with the petrology and mineral physics of each geologic unit within the NCM, which control the physical behavior of the solid mineral matrix within the rock.

This mineral physics database builds on the work of Abers and Hacker to include 13 minerals specific to continental rock types. We explored the effect of this database on zero-porosity anharmonic P- and S-wave rock velocities and density relative to a well-used empirical study of relations between wavespeeds and density by Brocher. We found that empirical relations between P-wave velocity and S-wave velocity or density do well on average but can differ from mineral physics calculations by up to 15 percent in S-wave velocity and almost 40 percent in density. This is consistent with Brocher's study where he obtained similar results for in situ measurements and laboratory rock specimens.

Additionally, the substantial presence of quartz in many rocks plays a major role in crustal seismic velocities and density due to quartz's $\alpha-\beta$ phase transition, which can interfere with these empirical relationships. With increasing depth, quartz P-wave velocity can suddenly jump by 15 percent accompanied by little change in S-wave velocity and a modest decrease in density. Empirical relations based on observed P-wave velocity where P-wave velocity is positively correlated with S-wave velocity and density would then significantly overestimate both S-wave velocity and density.

\section{Introduction}

Seismic hazards are nearly ubiquitous throughout the United States, and risk can be significant for some communities. The U.S. Geological Survey (USGS) is tasked with producing the National Seismic Hazard Maps (NSHMs), which have been developed and used to inform public policy, building codes, and emergency response protocols since the 1970s (Petersen and others, 2015). These maps are created based on source and ground motion models (GMMs), which are continuously updated and refined and fed into new hazard models.

Ground motion models within the current NSHM incorporate one or more model parameters that account for site response: (1) the time-averaged shear-wave velocity in the upper 30 meters (m) of the crust, known as $V_{S 30}$; and (2) the depths to shearwave velocities of 1.0 and 2.5 kilometers per second $(\mathrm{km} / \mathrm{s})$, known as $Z_{1.0}$ and $Z_{2.5}$. For consistency with previous practice, the 2014 hazard map applied a uniform $V_{S 30}$ of 760 meters per second $(\mathrm{m} / \mathrm{s})$ to the entire country with default values of $Z_{1.0}$ and $Z_{2.5}$, leaving refinement for specific site conditions to end users such as engineers. Due to spatial variability in subsurface physical properties and the application of relatively simple site response metrics, the implementation of constant $V_{S 30}$ and default values of $Z_{1.0}$ and $Z_{2.5}$ can cause substantial differences between ground motions estimated from the National Map and observed ground motions. The USGS is moving towards including maps for other $V_{S 30}$ values, accounting for spatially variable $Z_{1.0}$ and $Z_{2.5}$, and including knowledge gained from urban hazard mapping efforts (Moschetti and others, 2018). The work presented in this report supports these efforts through application of a National Crustal Model (NCM).

The USGS NCM data release (Boyd and Shah, 2018) is being developed to help better predict site response in a uniform way and on a national scale by providing site response metrics for GMMs. End users will still be able to carry out site specific analyses

${ }^{1}$ California State University, Sacramento, Calif.

${ }^{2}$ U.S. Geological Survey 
to improve estimates of site response, but we expect that application of the NCM will yield more accurate initial estimates relative to current USGS practice. Several current GMMs make use of $V_{S 30}, Z_{1.0}$, and $Z_{2.5}$, which can be extracted from the NCM, but the $\mathrm{NCM}$ will be able to provide potentially more meaningful metrics as well such as fundamental period or a fully frequency-dependent site-response function. As researchers move towards more broad scale application of three dimensional (3D) wavefield simulations in seismic hazard analyses, the NCM will also be able to provide 3D geophysical attribute volumes for such studies.

To estimate the site response parameters that are currently used or may be used in future GMMs, knowledge of the subsurface seismic velocity and density are needed. The current version of the NCM consists of geologic and geophysical profiles extending from the Earth's surface to the mantle and are defined by maps of sediment and rock type and age, depths to bedrock and basement, and models of subsurface porosity and temperature. Bulk density and seismic velocity are functions of these parameters. This report is concerned with the petrology and mineral physics of each geologic unit within the NCM, which control the physical behavior of the solid mineral matrix within the rock.

\section{Petrology}

The petrologic database consists of mineralogical compositions for the 209 geologic units that are present in the National Geologic Map of the United States (Schruben and others, 1994) of which 134 comprise the geologic profiles in the NCM. We define each geologic unit in our database by volume fractions of their respective mineral assemblages. Many of the units on the National Geologic Map, however, are not true "lithologies" but rather depositional environments or structural formations. Therefore, while crystalline rocks such as granites and limestones were easily defined in terms of mineral assemblage using standard nomenclature, in many instances some interpretation was necessary. For clarity, methods to determine petrology for each rock type are outlined in detail in the following sections.

\section{Igneous Rocks}

Mineral assemblages for igneous rocks were determined using the International Union of Geological Sciences (IUGS) Classification and Nomenclature standards (Le Maitre and others, 2002). To determine the range in composition for different igneous rocks, several steps were necessary (see appendix for an example for granodiorite). In brief, the mafic color index (Le Maitre and others, 2002) for a given rock type was interpreted to be a percentage range for the volume of mafic minerals present in the rock. Unless specifically stated in the literature (see rock specific notes in the petrology database [Sowers and Boyd, 2019]), Bowen's (1922) reaction series is used to determine the particular mafic minerals present. The remaining felsic mineral composition is obtained from the quartz-alkali feldspar-plagioclase-feldspathoid (QAPF) ternary diagram of Le Maitre and others (2002).

For volcanic rocks, the IUGS classification simply renames the fields in the QAPF ternary diagram. For instance, a rhyolite is defined within the same QAPF field as a granite. Therefore, for each location on the QAPF diagram, volcanic rocks were defined with the same mineral assemblages and volume fractions as the plutonic rocks. Volcanic rocks, however, cool more quickly than igneous rocks and may have a greater amount of glass, fewer mafic minerals, and a greater relative concentration of mafic minerals toward the upper end of Bowen's reaction series. For this version of the database, we have not modeled these effects.

\section{Metamorphic Rocks}

The IUGS Metamorphic Rocks Classification (Fettes and Desmons, 2007) for the most part does not define lithologies based on mineral assemblage, but rather on structural features such as schistosity. In many cases, the USGS Mineral Resources interactive geologic map at https://mrdata.usgs.gov/geology/state/map-us.html (USGS, 2017) was used to narrow the definition of the unit to a specific location where background literature was used to define the mineral assemblage. For the subduction zone facies, the Hacker and Abers (2004) mineral assemblages were used to determine the mean composition as well as the range of compositions.

In instances where the structural rock type was too geographically widespread (such as was the case for the geologic unit "gneiss"), the mineral assemblage and volume fractions were taken to be similar enough to those of granite for the purposes of this study.

\section{Sedimentary Rocks}

For well-defined sedimentary rocks, such as arkose and limestone, nomenclature defined in Folk (1980) and Boggs (2006) was used primarily. For the poorly defined sedimentary rocks, such as sandstone and conglomerate, general terrigenous sediment composition after Folk (1980) was used. General compositions of sediments are described in table 1. 
Table 1. General compositions of terrigenous and evaporite sediments. Relative abundance of minerals in the sedimentary rocks, adapted from Folk (1980).

\begin{tabular}{lclc}
\hline $\begin{array}{c}\text { Terrigenous Minerals': } \\
\text { Derived from erosion and weathering of continental } \\
\text { materials (percent) }\end{array}$ & \multicolumn{2}{c}{$\begin{array}{c}\text { Evaporite Minerals } \\
\text { (percent) }\end{array}$} \\
\hline Quartz $^{2}$ & $41-69$ & Carbonates $^{5}$ & $70-85$ \\
Clay minerals $^{3}$ & $25-35$ & Silica (quartz) & $10-15$ \\
Feldspars $^{4}$ & $5-15$ & Sulfates and salts & $2-7$ \\
Carbonates $^{5}$ & $1-4$ & Feldspar & $2-7$ \\
\hline
\end{tabular}

\footnotetext{
${ }^{1}$ Trace minerals (coarse micas $0.1-0.4$ percent and opaques $0.1-1.0$ percent) were excluded from rock compositions.

${ }^{2}$ Includes chert and metamorphic rock fragments.

${ }^{3}$ Equal parts kaolinite, illite, and montmorillonite.

${ }^{4}$ Anorthite and orthoclase for simplicity.

${ }^{5}$ Calcite.

${ }^{6}$ Halite.
}

\section{Sediments}

Many of the unconsolidated lithologic units represent unconsolidated sediments, structural formations, and depositional environments rather than true lithologies. By filtering the shapefiles available from USGS Mineral Resources (https://mrdata.usgs.gov/geology/state/) for individual units within each state, it was found that some of the units within the map were only defined in a limited geographic context (in many cases, these units were only present in a single state). Other units, however, were found in nearly every state. It was necessary to take a slightly different approach for each instance to determine the mineral assemblage for these units.

\section{Limited Geographic Definition}

For the units that were only defined in a limited geographic context, the USGS Mineral Resources interactive geologic map (USGS, 2017, https://mrdata.usgs.gov/geology/state/map-us.html) was used to determine what, if any, clarifying information was available. This information was often in the form of a specific formation name. Where possible, the original paper describing the formation was used to define the mineral assemblage. Where this clarifying information was unavailable, general terrigenous sediment composition after Folk (1980) was used (see table 1).

\section{Broad Geographic Definition}

For the units that were defined over a broad geographic area, a type location (specified in the petrologic database at https://doi.org/10.5066/P9HN170G) (Sowers and Boyd, 2019) was selected based on relative concentration compared to other locations and relative seismic hazard. For example, the geologic unit "playa" was found in Nevada, Utah, Wyoming, and Montana. The highest concentration of the unit was found in Nevada. Therefore, the "playa" unit was defined in terms of mineral assemblage based on the composition of the Nevada playas. In this instance, the term "playa" was interpreted to mean "dry lake deposit," and, therefore, the mineral composition for "lake or marine sediments" was used for "playa."

\section{Mineral Physics}

We began with the mineral physics database originally compiled by Hacker and Abers (2004), which was updated in 2016 (Abers and Hacker, 2016; HA16). Several of the lithologic units we considered, however, are composed of minerals that are not in these databases. We consulted the literature to add 13 unique minerals to HA16 (table 2). For completeness, reported variants of these minerals are included in the database. See the mineral physics database for parameter values and additional notes in the ScienceBase data release that supports this report at https://doi.org/10.5066/P9HN170G (Sowers and Boyd, 2019). 
Table 2. The 13 minerals added to Albers and Hacker (2016) updated database referred to here as HA16. Footnotes in bold are methods for parameter estimation implemented in the original HA16 database. All values are at standard temperature and pressure.

[ $\rho$, density, kilograms per cubic meter; $\alpha_{0}$, thermal expansivity, one over Kelvin; $K_{\mathrm{T}}$, isothermal bulk modulus, Pascals; $K_{\mathrm{T}}{ }^{\prime}$, pressure derivative of the isothermal bulk modulus, dimensionless; $G$, shear modulus, Pascals; $\Gamma$, $=(\partial \ln G / \partial \ln \rho)_{P}$, dimensionless; $G^{\prime}$, pressure derivative of the shear modulus, dimensionless; $\gamma_{\text {th }}$, first Grüneisen parameter, dimensionless; $\delta_{\mathrm{T}}$, second Grüneisen parameter, dimensionless]

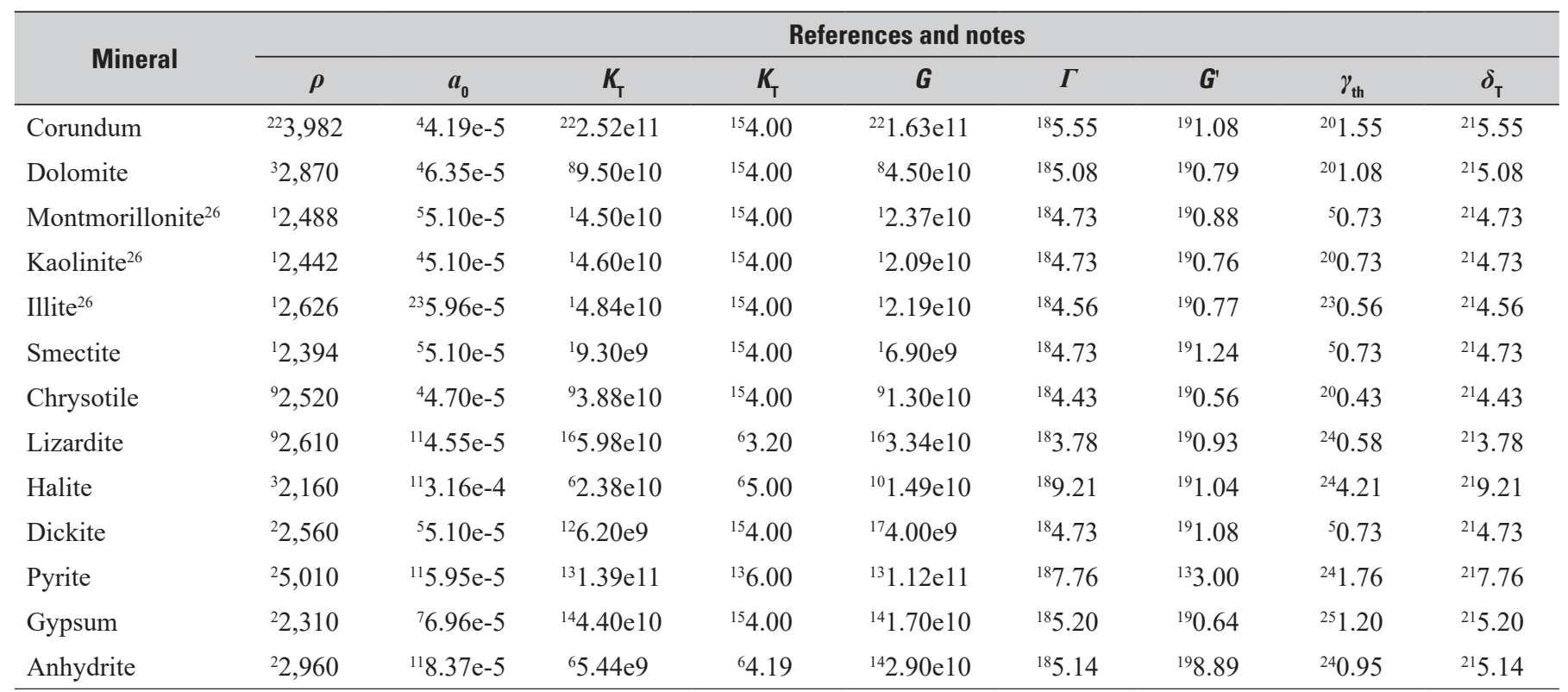

${ }^{1}$ Wang and others (2001).

${ }^{2}$ Barthelmy (2012).

${ }^{3}$ Russian Academy of Sciences (2008)

${ }^{4}$ Holland and Powell (1998) values and expansion for thermal expansivity: $\alpha(T)=\alpha_{0}\left(1-10 / T^{1 / 2}\right)$, giving $\ln \left(V(T) / V_{0}\right)=\alpha_{0}\left(\left(\mathrm{~T}-298-20\left(T^{1 / 2}-298^{1 / 2}\right)\right)\right.$, where $T$ is temperature in Kelvin and $V$ is volume.

${ }^{5}$ Values for kaolinite assumed.

${ }^{6}$ Holland and Powell (2011).

${ }^{7}$ Schofield and others (1996).

${ }^{8}$ Carmichael (1989).

${ }^{9}$ Reynard and others (2007).

${ }^{10}$ Presentation by Gary Mavko (2005).

${ }^{11}$ Holland and Powell (2011) values with a correction to be able to use Holland and Powell (1998) expansion for thermal expansivity: $\alpha(T)=\alpha_{0}\left(1-10 / T^{1 / 2}\right)$, see text.

${ }^{12}$ Prasad and others (2002).

${ }^{13}$ Whitaker and others (2010).

${ }^{14}$ Meille and Garboczi (2001).

${ }^{15}$ Common value assumed (Anderson, 1989).

${ }^{16}$ Ghaderi and others (2015).

${ }^{17}$ Vanorio and others (2003), using lower limit of shear modulus to match bulk modulus found by (Prasad and others, 2002).

${ }^{18}$ Approximated as $\Gamma=\delta_{\mathrm{T}}$ (Anderson and others, 1992).

${ }^{19}$ Approximated as $G^{\prime}=\left(5^{*} G\right) /\left(3 * K_{\mathrm{T}}\right)$ (Anderson and others, 1992).

${ }^{20} \gamma_{\text {th }}$ was calculated using Bina and Helffrich (1992) equation (16) at $1,000{ }^{\circ} \mathbf{K}$, using Holland and Powell (1998) values: NOTE: $V$ and $K$ from Holland and Powell are calculated at $298^{\circ} \mathrm{K}$ whereas $\alpha$ is calculated at $1,000^{\circ} \mathrm{K}$.

${ }^{21}$ Approximated as $\delta_{\mathrm{T}}=\gamma_{\mathrm{th}}+K_{\mathrm{T}}{ }^{\prime}$ (Anderson and others, 1992).

${ }^{22}$ Anderson and others (1992).

${ }^{23}$ Values for muscovite assumed.

${ }^{24} \gamma_{\text {th }}$ was calculated using Bina and Helffrich (1992) equation (16) at $1,000{ }^{\circ} \mathrm{K}$, using Holland and Powell (2011) values.

${ }^{25} \mathrm{Knittle}$ and others (2001).

${ }^{26}$ Values are averages of the variants in the database. 


\section{Mineral and Rock Seismic Velocity and Density}

Differences in mineral physical properties can lead to strong variations in seismic velocities and densities. In figure 1, we show the variation in S-wave velocity, $V_{\mathrm{S}}$, and density, $\rho$, versus $\mathrm{P}$-wave velocity, $V_{\mathrm{P}}$, for the minerals in our database at standard temperature and pressure (STP). Values for each mineral as a function of temperature and pressure are calculated using the Matlab routine MinVel.m (Boyd, 2019), which is a mineral physics formulation originally described in section 3 of the supporting material by Boyd and others (2004) and based on the work of Bina and Helffrich (1992), Holland and Powell (1998), and Hacker and Abers (2004). We further modify our calculations for quartz using the method described in Abers and Hacker (2016). Upon comparison of our method with the routines in Abers and Hacker (2016) for each mineral in their database, we find that differences in $V_{\mathrm{P}}, V_{\mathrm{S}}$, and $\rho$, varying along continental pressure gradients and geotherms between 0 and $80 \mathrm{~km}$ depth and 0 and $1,200^{\circ} \mathrm{C}$, are less than 1 percent.

At STP, mineral densities vary from 2,200 to over 5,000 kilograms per cubic meter $\left(\mathrm{kg} / \mathrm{m}^{3}\right), V_{\mathrm{p}}$ from 2,100 to $11,000 \mathrm{~m} / \mathrm{s}$, and $V_{\mathrm{S}}$ from 1,250 to $6,400 \mathrm{~m} / \mathrm{s}$. Densities tend to increase with increasing $V_{\mathrm{P}}$ as does $V_{\mathrm{S}}$, but the correlation between $V_{\mathrm{S}}$ and $V_{\mathrm{P}}$ is much stronger. Empirical relations for crustal $\rho$ and $V_{\mathrm{S}}$ as functions of $V_{\mathrm{P}}$ (Brocher, 2005), valid between 1,500 and 8,500 m/s $V_{\mathrm{P}}$, follow these trends well. The 7 most abundant minerals by volume within the 70 uniquely defined rock and sediment compositions are indicated by red circles. While the empirical curves do well on average, the $V_{\mathrm{p}}-V_{\mathrm{S}}$ relation underpredicts the shear-wave velocity of smectite by 40 percent and overpredicts calcite by 10 percent. The $V_{\mathrm{p}}-\rho$ relation underpredicts the density of smectite by 10 percent and overpredicts low albite by 7 percent. But figure 1, however, does not tell the whole story, particularly with respect to quartz.

Quartz, the most abundant mineral by far in the Earth's crust, has some exceptionally unusual properties (Ohno and others, 2006), which become even more evident with increasing pressure and temperature. At low temperatures, $\alpha$ quartz is stable in the upper crust and transforms to $\beta$ quartz at higher temperature. In addition to the former having an unusually low Poisson's ratio of less than 0.1 at STP, the temperature dependence of the mineral's physical properties is far different from other minerals resulting in a unique treatment of its thermal expansivity and modulus (Abers and Hacker, 2016). Further, $\beta$ quartz also has unusual properties, which are very different from $\alpha$ quartz, necessitating, as a potential solution, a temperature dependence in: (1) the logarithmic derivative of the shear modulus with respect to density, $\Gamma$; and (2) the second Grüneisen parameter, $\delta_{\mathrm{T}}$ (Abers and Hacker, 2016). We implement these solutions recognizing, as they note, that the elastic properties of quartz have not been measured simultaneously at both elevated pressure and temperature.

Following reasonable temperature and pressure gradients into the crust, most minerals' density and elastic wave speeds actually decrease (fig. 2). Quartz begins on a similar trajectory but then changes direction as the phase change is approached. Wave speeds then increase with depth. And after the transition from $\alpha-\beta$ quartz, which, for a uniform thermal gradient of $30{ }^{\circ} \mathrm{C} / \mathrm{km}$ and density of $2,700 \mathrm{~kg} / \mathrm{m}^{3}$, would occur at $740{ }^{\circ} \mathrm{C}$ and $25 \mathrm{~km}$ depth (Shen and others, 1993), Poisson's ratio jumps to a more standard value but increases quickly, as does P-wave velocity. The strong change in P-wave velocity across the transition could lead to a measurable reflector in the mid-crust, and variations in the P-wave velocity of quartz has been exploited to estimate the temperature and composition within the crust (Kuo-Chen and others, 2012; Sheehan and others, 2014).

In figure 3, we show $V_{\mathrm{P}}, V_{\mathrm{S}}$, and $\rho$ at STP for the rock types in the petrologic database including 5 of the top 11 occurring in the NCM: lake and marine sediment, sandstone, limestone, basalt, and granite. These calculations assume zero porosity, a Voigt-Reuss-Hill average of the moduli of constituent minerals, and no seismic attenuation. These five rock types have a modest range of physical properties $-V_{\mathrm{P}}$ that varies by 25 percent from largest to smallest, $V_{\mathrm{S}}$ by 25 percent, and $\rho$ by almost 10 percent. When considering all rock types with unique compositions as defined in the petrologic database $(\mathrm{n}=70)$, differences between estimates of $V_{\mathrm{S}}$ from the empirical relation given $V_{\mathrm{p}}$ and those calculated from mineral physics are less than 1 percent on average with a standard deviation of 5 percent. Differences between empirical and mineral physics estimates of density are within about 1 percent on average with a standard deviation of 8 percent. Deviations from the empirical relations of up to 15 percent in S-wave velocity and 37 percent in density are possible. This was recognized in the study of Brocher (2005) based on in situ and laboratory measurements.

These values may increase or decrease with depth depending on the pressure gradient and geotherm and the pressure and temperature dependence of constituent minerals. In figure 4, we show changes in physical properties assuming that pressure increases linearly due to the overburden of rock having a density of $2,700 \mathrm{~kg} / \mathrm{m}^{3}$ and temperature increases according to either a moderate $\left(90 \mathrm{~mW} / \mathrm{m}^{2}\right.$ surface heat flow) or hot geotherm $\left(120 \mathrm{~mW} / \mathrm{m}^{2}\right)$, as might be found in the western United States, using the constants and formulation assumed for figure 2. Increasing pressure tends to increase seismic velocity and density whereas increasing temperature usually does the opposite. These factors lead to $V_{\mathrm{P}}, V_{\mathrm{S}}$, and $\rho$ that decrease with depth for the five rock types considered until the transition to $\beta$ quartz. After the transition, which increases in depth from $\sim 20$ to $50 \mathrm{~km}$ as the geotherm decreases from 120 to $90 \mathrm{~mW} / \mathrm{m}^{2}$, P-wave velocities jump and may continue to increase for rock types with large fractions of quartz. S-wave velocities experience a smaller jump and densities drop. The $V_{\mathrm{P}} / V_{\mathrm{S}}$ ratio may increase or decrease with depth depending on rock type and the presence of quartz. Sandstone and granite, rock types assigned average values of 55 percent and 35 percent quartz, respectively, have ratios that initially decrease with depth. After the transition to $\beta$ quartz, P-wave velocity jumps as do the ratios, and the ratios continue to increase with depth, similar to other rock types. 

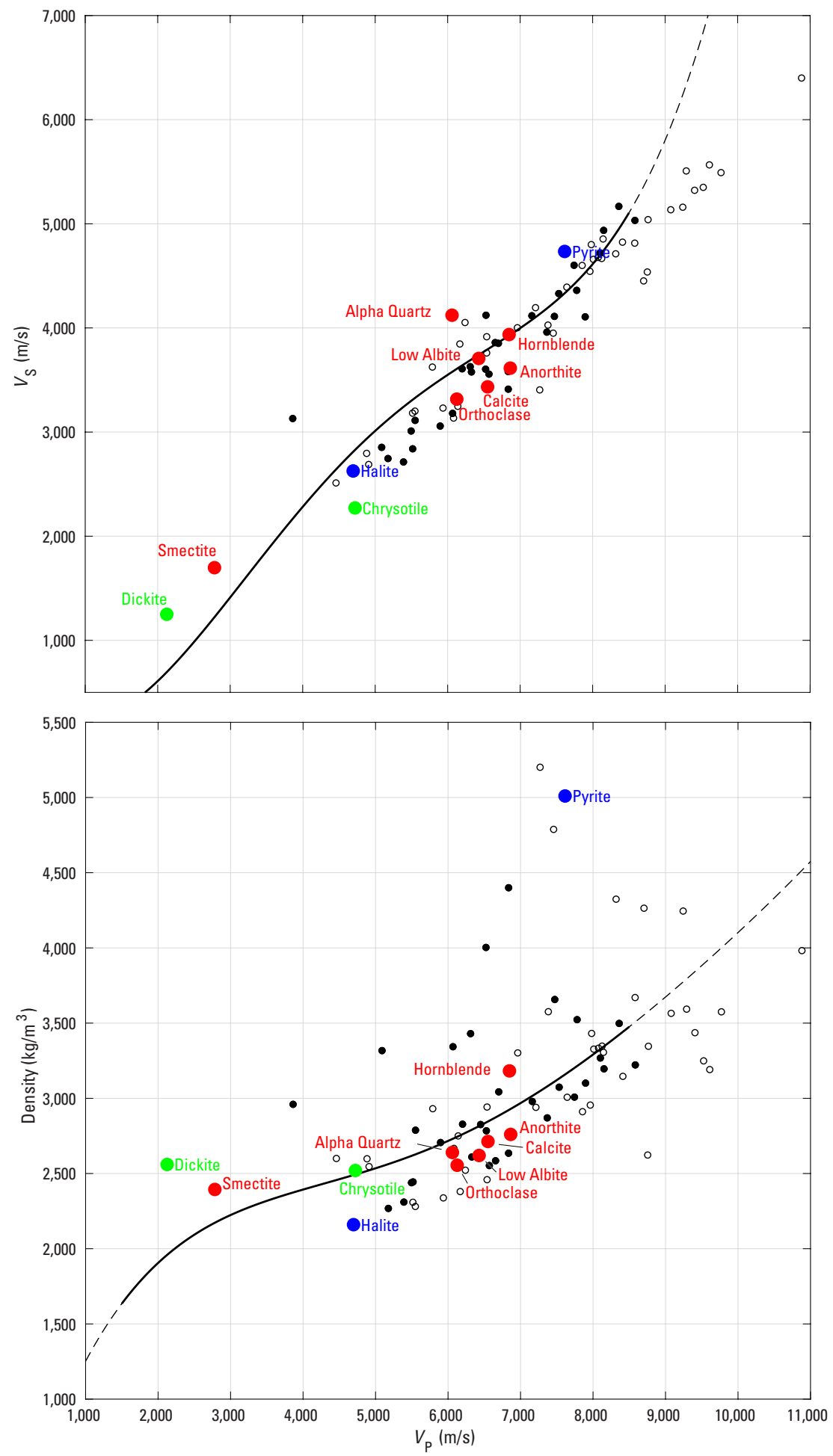

Figure 1. S-wave velocity $\left(V_{s}\right)$ and density versus $\mathrm{P}$-wave velocity $\left(V_{\mathrm{p}}\right)$ for each mineral in the National Crustal Model (NCM) ScienceBase mineral physics database that supports this report (Sowers and Boyd, 2019, at https://doi.org/10.5066/P9HN170G) at standard temperature and pressure. Filled symbols are minerals that are currently used for each rock type in the NCM petrology database. The solid lines are the empirical relations of Brocher (2005) within the recommended range of $V_{p}$; it is dashed outside of this range. Red circles are the five best-represented minerals in the petrology database by volume. Blue circles indicate the minerals with extremes in density; green circles, extremes in S-wave velocity relative to the empirical relation. $\mathrm{m} / \mathrm{s}$; meters per second; $\mathrm{kg} / \mathrm{m}^{3}$; kilograms per cubic meter. 

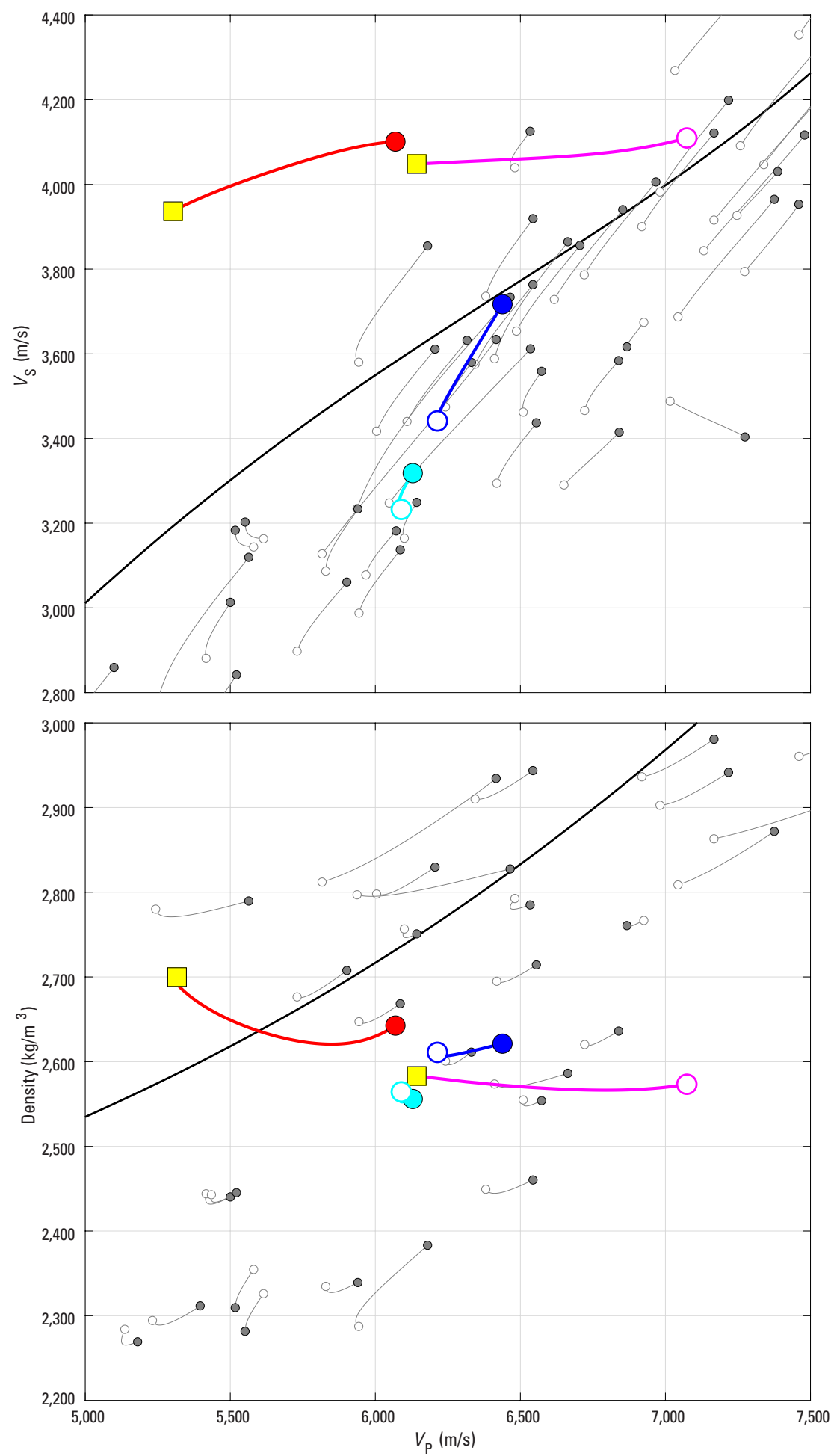

Figure 2. Combined temperature and pressure dependence of minerals in the National Crustal Model (NCM) ScienceBase mineral physics database that supports this report (Sowers and Boyd, 2019, at https://doi.org/10.5066/P9HN170G). Temperature increases from the surface (solid circles) to 50 kilometers $(\mathrm{km})$ depth (open circles) following a heat producing geotherm with surface heat flow of 100 milliwatts per square meter $\left(\mathrm{mW} / \mathrm{m}^{2}\right)$, mantle heat flow of $20 \mathrm{~mW} / \mathrm{m}^{2}$, thermal conductivity of 2.5 watts per meter-Kelvin $(\mathrm{W} / \mathrm{mK})$, and depth over which heat production decreases by a factor of e of $20 \mathrm{~km}$ (Turcotte and Schubert, 1982; equation 4-31). Pressure increases due to the overburden of rock with a density of 2,700 kilogram per cubic meter $\left(\mathrm{kg} / \mathrm{m}^{3}\right)$. Red curve and symbol represent $\alpha$ quartz; magenta, $\beta$ quartz; blue, low albite; and cyan, orthoclase. The yellow square occurs at the transition from $\alpha-\beta$ quartz, $800{ }^{\circ} \mathrm{C}$ and $35 \mathrm{~km}$ depth. $V_{\mathrm{p}}$ P-wave velocity; $\mathrm{m} / \mathrm{s}$, meters per second. 

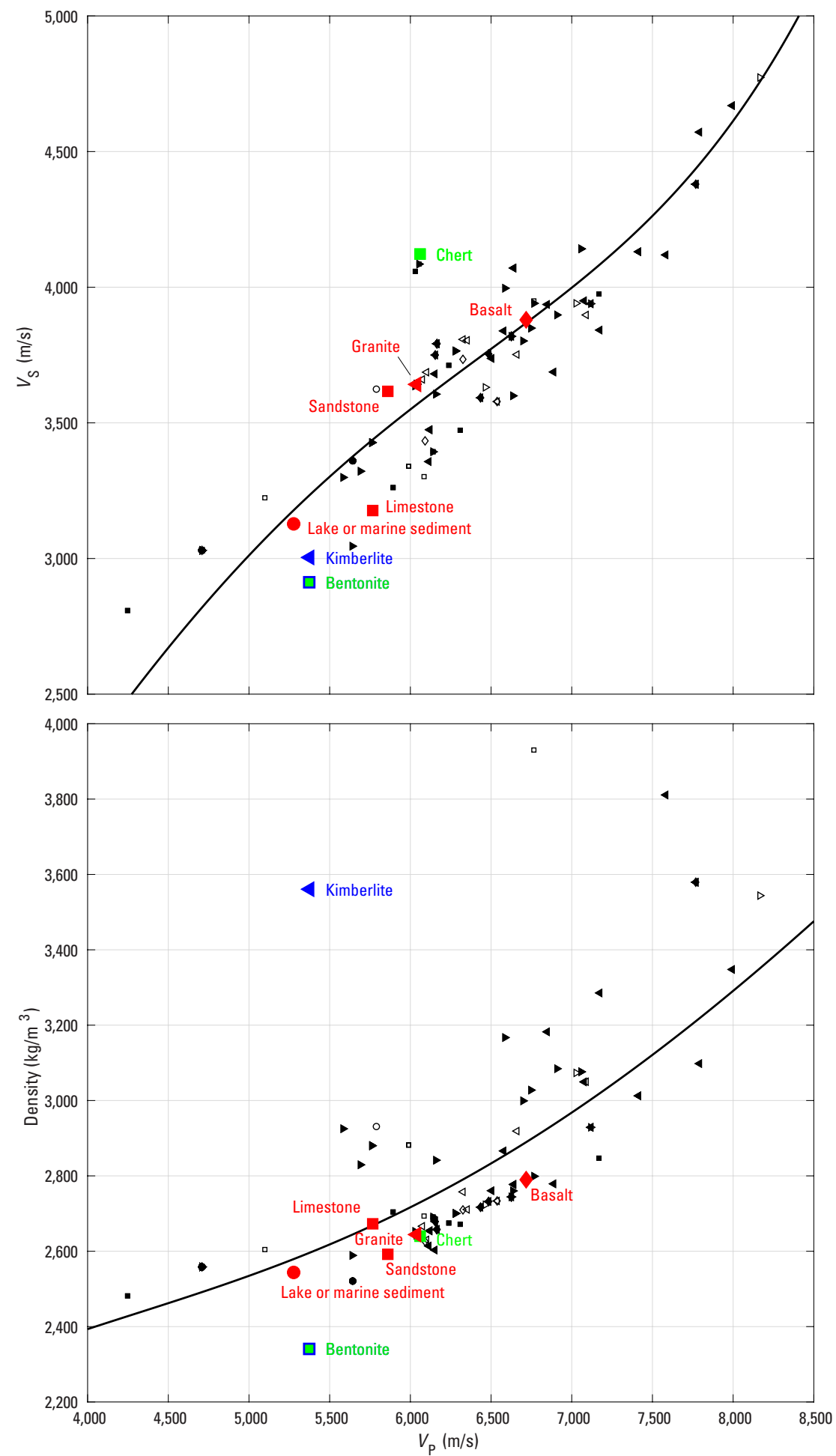

Figure 3. S-wave velocity $\left(V_{S}\right)$ and density versus $\mathrm{P}$-wave velocity $\left(V_{\mathrm{P}}\right)$ for each rock type in the ScienceBase petrology database that supports this report (Sowers and Boyd, 2019, at https://doi.org/10.5066/P9HN170G) at standard temperature and pressure with no porosity or anelasticity. Filled symbols are rock types that are currently present in the National Crustal Model. The solid lines are the empirical relations of Brocher (2005). Circles are unconsolidated geologic units; squares, sedimentary rocks; diamonds, extrusive volcanics; left-facing triangles, igneous; and right-facing triangles, metamorphic; $\mathrm{m} / \mathrm{s}$, meters per second; $\mathrm{kg} / \mathrm{m}^{3}$, kilograms per cubic meter. Red symbols reflect a variety of well-represented rock types; blue symbols indicate the rock types with extremes in density; and green, extremes in S-wave velocity, relative to the empirical relation. 
For comparison, we show in figure 4 the empirical relationships of Brocher (2005) for $V_{\mathrm{S}}, V_{\mathrm{P}} / V_{\mathrm{S}}$, and density given $V_{\mathrm{P}}$ (dashed lines), relationships that are used regularly to estimate S-wave velocities and densities in 3D seismic velocity models (Aagaard and others, 2010; Stephenson and others, 2017). Using these empirical relations, $V_{\mathrm{S}}$ is well estimated for basalt in the near surface but is overestimated for limestone by almost 10 percent. These differences increase with depth, particularly after the transition to $\beta$ quartz. Sandstone and granite go from being underpredicted by about 6 percent just above the transition to being overpredicted by about 5 percent below. Density, on the other hand, is well estimated for limestone but overestimated for basalt and the other three rock types. Like $V_{\mathrm{s}}$, this difference increases significantly, especially for quartz-bearing rock types after the transition to $\beta$ quartz, exceeding 7 percent for granite.
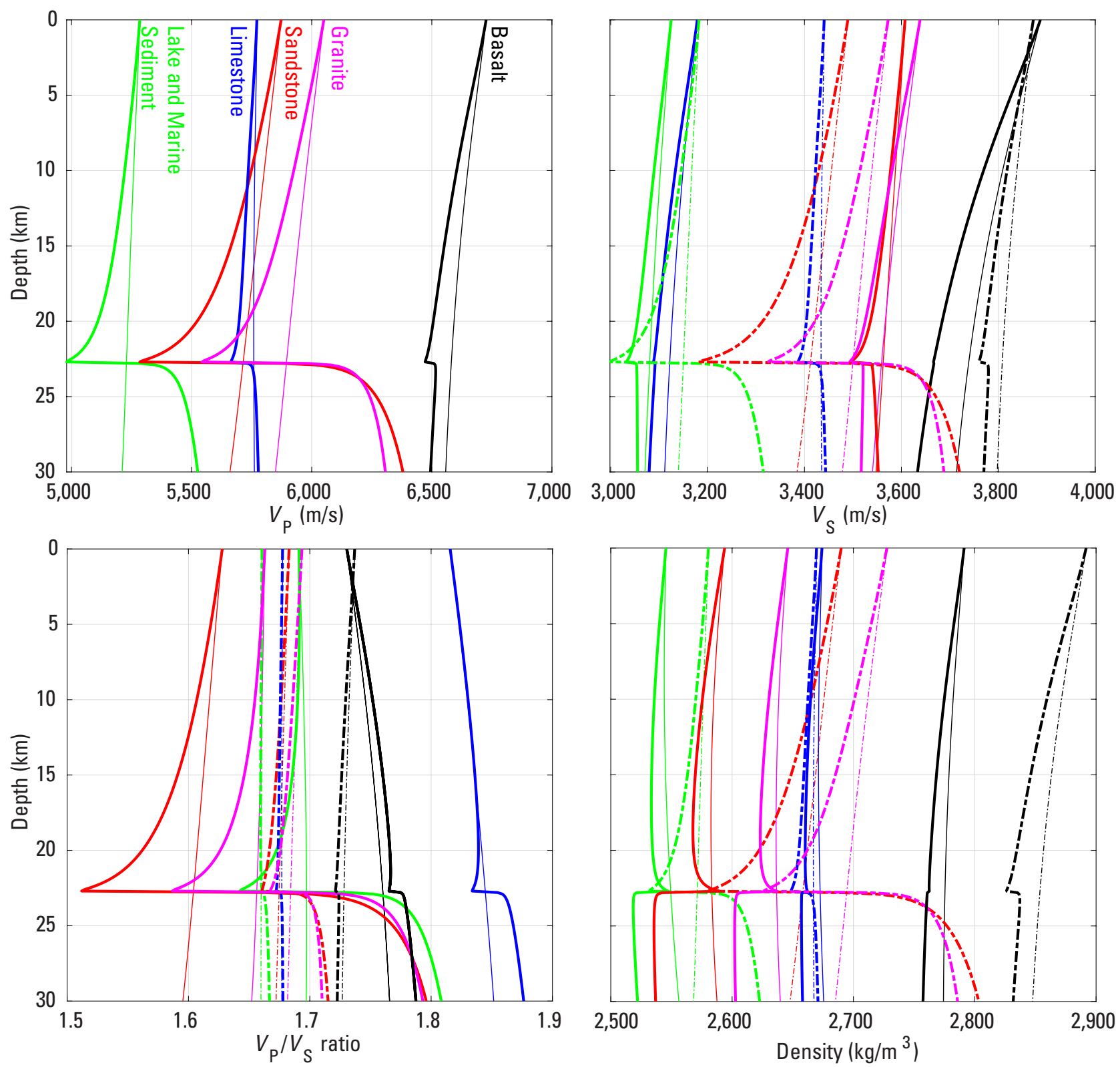

Figure 4. Estimates of P-wave velocity $\left(V_{\mathrm{p}}\right), \mathrm{S}$-wave velocity $\left(V_{\mathrm{S}}\right), V_{\mathrm{p}} / V_{\mathrm{S}^{\prime}}$ and $\rho$ versus depth for several well-represented upper crustal rock types. Solid lines result from mineral physics calculations. Dashed-dot lines result from the empirical relations of Brocher (2005). The thin lines represent a moderate geotherm $\left(90\right.$ [milliwatts per square meter] $\left.\mathrm{mW} / \mathrm{m}^{2}\right)$ and the thick lines, a hot $\left(120 \mathrm{~mW} / \mathrm{m}^{2}\right)$ geotherm. Note that these values do not account for anelasticity or porosity, which will act to reduce velocity and density towards the Earth's surface. $\mathrm{kg} / \mathrm{m}^{3}$, kilograms per cubic meter; $\mathrm{km}$, kilometers. 
Porosity, which is not considered in this report but is a major element of the NCM, is a primary factor controlling seismic velocities and densities within several kilometers of the Earth's surface. Porosity increases towards the Earth's surface and decreases seismic velocities (Lee, 2010) and rock densities. The effect is more pronounced for $V_{\mathrm{S}}$, thereby moving $V_{\mathrm{p}} / V_{\mathrm{S}}$ to higher values near the Earth's surface. Within several hundred meters of the Earth's surface, the $V_{\mathrm{P}} / V_{\mathrm{S}}$ ratio can be highly variable with values far greater than 2 depending on the saturation. Unfortunately, these large and highly variable values of $V_{\mathrm{P}} / V_{\mathrm{S}}$ generally occur where $V_{\mathrm{p}}$ drops below the limit of $1,500 \mathrm{~m} / \mathrm{s}$ set for the empirical relation of Brocher (2005) necessitating an alternative approach to estimating physical properties. Application of a porosity model within the NCM aims to address this issue.

Other phenomena not directly considered in this report are the effects of mineral anelasticity and other contributors to seismic attenuation, which will also act to slow $V_{\mathrm{S}}$ more than $V_{\mathrm{P}}$, thereby increasing the $V_{\mathrm{P}} / V_{\mathrm{S}}$ ratio. The anelastic effect is temperature dependent (Karato, 1993) but is expected to be minimal at shallow depths and where temperatures are significantly less than the melting temperature. Other forms of seismic attenuation, however, such as fluid flow (Winkler and Nur, 1982; Chapman and others, 2016), will become dominant at shallow depths in the presence of appreciable porosity.

\section{Conclusion}

We present a petrologic and mineral physics database for the NCM. Mineral assemblages for 209 rock types are defined using general classifications in the literature with refinement for several specific geologic formations. The mineral physics database builds on the work initiated by Hacker and Abers (2004) and most recently revised in Abers and Hacker (2016) in which we add 13 minerals relevant to more continental rock types. We calculate P-wave and S-wave velocities and density for the rock types in the petrologic database and compare these results with the empirical relationships of Brocher (2005). We find that on average the empirical relationships are similar to values calculated here at standard pressure and temperature. Deviations about the average are generally modest for several well-represented rock types, but when considering all rock types, we find that due to specific mineral physical properties, $V_{\mathrm{S}}$ and $\rho$ empirically derived from $V_{\mathrm{P}}$ can deviate from mineral physics calculations by up to 15 percent and 37 percent, respectively.

The effects of pressure, temperature, porosity, and anelasticity complicate the correlation between the empirical relations and mineral physics calculations. We account for pressure and temperature and show that the presence of quartz can exhibit exceptionally unusual physical behavior because of the potential transition from $\alpha-\beta$ quartz within the crust. The effects of porosity and attenuation will be addressed in other work related to building the National Crustal Model.

Application of this database to geologic and thermal models will yield mineral velocities and densities that vary with pressure and temperature according to established theory and experimental data. Coupled with theory accounting for the effects of porosity (Lee, 2010) and attenuation (Karato, 1993; Chapman and others, 2016) and calibration with in situ velocity and density datasets, application of the resulting geophysical model should result in more accurate and uniformly derived estimates of site response and seismic hazard and risk across the nation.

\section{References Cited}

Aagaard, B.T., Graves, R.W., Rodgers, A., Brocher, T.M., Simpson, R.W., Dreger, D., Petersson, N.A., Larsen, S.C., Ma, S., and Jachens, R.C., 2010, Ground motion modeling of Hayward fault scenario earthquakes, Part II-Simulation of long-period and broadband ground motions: Bulletin of the Seismological Society of America, v. 100, no. 6, p. 2945-2977. [Also available at https://doi.org/10.1785/0120090379.]

Abers, G.A., and Hacker, B.R., 2016, A MATLAB toolbox and Excel workbook for calculating the densities, seismic wave speeds, and major element composition of minerals and rocks at pressure and temperature: Geochemistry, Geophysics, Geosystems, v. 16, p. 616-624, accessed December 10, 2018, at https://doi.org/10.1002/2015GC006171.

Anderson, D.L., 1989, Theory of the Earth: Malden, Mass., Blackwell Science, Inc, 366 p.

Anderson, O.L., Isaak, D., and Oda, H., 1992, High-temperature elastic constant data on minerals relevant to geophysics: Reviews of Geophysics, v. 30, no. 1, p. 57-90. [Also available at https://doi.org/10.1029/91RG02810.]

Barthelmy, D., 2012, Mineralogy database: Spring, Tex., David Barthelmy Consulting, accessed on June 12, 2017, at http://webmineral.com/data. 
Bina, C.R., and Helffrich, G.R., 1992, Calculation of elastic properties from thermodynamic equation of state principles: Annual Review of Earth and Planetary Sciences, v. 20, p. 527-552. [Also available at https://www.annualreviews.org/doi/ pdf/10.1146/annurev.ea.20.050192.002523.]

Boggs, S., Jr., 2006, Principles of Sedimentology and Stratigraphy (4th ed.): Upper Saddle River, N.J., Pearson Education, Inc., $565 \mathrm{p}$.

Bowen, N.L., 1922, The reaction principle in petrogenesis: Journal of Geology, v. 30, no. 3, p. 177-198. [Also available at https://www.journals.uchicago.edu/doi/pdfplus/10.1086/622871.]

Boyd, O.S., Jones, C.H., and Sheehan, A.F., 2004, Foundering lithosphere imaged beneath the southern Sierra Nevada, California: Science, v. 305, p. 660-663. [Also available at https://doi.org/10.1126/science.1099181.]

Boyd, O.S., and Shah, A.K., 2018, Layers of the USGS National Crustal Model: U.S. Geological Survey data release, https://doi.org/10.5066/P9T96Q67.

Boyd, O.S., 2019, MinVel—A Matlab routine to calculate mineral physics parameters in dependence on temperature and pressure: U.S. Geological Survey, GitHub, https://github.com/usgs/MinVel.

Brocher, T.M., 2005, Empirical relations between elastic wavespeeds and density in the Earth's crust: Bulletin of the Seismological Society of America, v. 95, no. 6, p. 2081-2092. [Also available at https://pubs.geoscienceworld.org/ssa/bssa/ article/95/6/2081/146858/empirical-relations-between-elastic-wavespeeds-and.]

Carmichael, R.S., 1989, Practical handbook of physical properties of rocks and minerals: Boca Raton, Fla., CRC Press, 756 p.

Chapman, S., Tisato, N., Quintal, B., and Holliger, K., 2016, Seismic attenuation in partially saturated Berea Sandstone submitted to a range of confining pressures: Journal of Geophysical Research, v. 121, no. 3, p. 1664-1676, accessed December 13, 2018, at https://doi.org/10.1002/2015JB012575.

Fettes, D.J., and Desmons, J., eds., 2007, Metamorphic Rocks-A Classification and glossary of terms, recommendations of the International Union of Geological Sciences Subcommission on the systematics of metamorphic rocks: Cambridge, Cambridge University Press, 256 p.

Folk, R.L., 1980, Petrology of sedimentary rocks: Austin, Tex., Hemphill Publishing Company, 182 p.

Ghaderi, N., Zhang, H., and Sun, T., 2015, Relative stability and contrasting elastic properties of serpentine polymorphs from first-principles calculations: Journal of Geophysical Research, v. 120, p. 4831-4842, accessed November 8, 2018, at https://agupubs.onlinelibrary.wiley.com/doi/pdf/10.1002/2015JB012148.

Hacker, B.R., and Abers, G.A., 2004, Subduction Factory 3-An Excel worksheet and macro for calculating the densities, seismic wave speeds, and $\mathrm{H}_{2} \mathrm{O}$ contents of minerals and rocks at pressure and temperature: Geochem. Geophys. Geosys., v. 5, no. Q01005. [Also available at https://doi.org/10.1029/2003GC000614.]

Holland, T.J., and Powell, R., 1998, An internally consistent thermodynamic data set for phases of petrological interest: Journal of Metamorphic Petrology, v. 16, p. 309-343. [Also available at https://doi.org/10.1111/j.1525-1314.1998.00140.x.]

Holland, T.J.,2011, An improved and extended internally consistent thermodynamic dataset for phases of petrological interest, involving a new equation of state for solids: Journal of Metamorphic Petrology, v. 29, p. 333-383. [Also available at https://doi.org/10.1111/j.1525-1314.2010.00923.x.]

Karato, S.-i., 1993, Importance of anelasticity in the interpretation of seismic tomography: Geophysical Research Letters, v. 20, no. 15, p. 1623-1626. [Also available at https://doi.org/10.1029/93GL01767.]

Knittle, E., Phillips, W., and Williams, W., 2001, An infrared and Raman spectroscopic study of gypsum at high pressures: Physics and Chemistry of Minerals, v. 28, p. 630-640. [Also available at https://link.springer.com/article/10.1007/ s002690100187.]

Kuo-Chen, H., Wu, F.T., Jenkins, D.M., Mechie, J., Roecker, S.W., Wang, C.-Y., and Huang, B.-S., 2012, Seismic evidence for the $\alpha-\beta$ quartz transition beneath Taiwan from Vp/Vs tomography: Geophysical Research Letters, v. 39, p. L22302. [Also available at https://agupubs.onlinelibrary.wiley.com/doi/pdf/10.1029/2012GL053649.] 
Le Maitre, R.W., ed., Streckeisen, A., Zannetin, B., Le Bas, M.J., Bonin, B., Bateman, P., Bellieni, G., Dudek, A., Efremova, S., Keller, J., Lameyre, J., Sabine, P.A., Schmid, R., Sørensen, H., and Wooley, A.R., 2002, Igneous Rocks-A classification and glossary of terms, Recommendations of the International Union of Geological Sciences Subcommission on the Systematics of Igneous Rocks: Cambridge, Cambridge University Press, 254 p.

Lee, M.W., 2010, Predicting S-wave velocities for unconsolidated sediments at low effective pressure: U.S. Geological Survey Scientific Investigations Report 2010-5138, 13 p. [Also available at https://doi.org/10.3133/sir20105138.]

Mavko, G., 2005, Elasticity, Stanford rock physics laboratory, notes from GP 262—Rock Physics, spring 2005: Stanford University, accessed June 9, 2017, at https://pangea.stanford.edu/courses/gp262/Notes/5.Elasticity.pdf.

Meille, S., and Garboczi, E.J., 2001, Linear elastic properties of 2D and 3D models of porous materials made from elongated objects: Modelling and Simulation in Material Science and Engineering, v. 9, p. 371-390. [Also available at https://iopscience.iop.org/article/10.1088/0965-0393/9/5/303.]

Moschetti, M.P., Luco, N., Frankel, A.D., Petersen, M.D., Aagaard, B.T., Baltay, A.S., Blanpied, M.L., Boyd, O.S., Briggs, R.W., Gold, R.D., Graves, R.W., Hartzell, S.H., Rezaeian, S., Stephenson, W.J., Wald, D.J., Williams, R.A., and Withers, K.B., 2018, Integrate urban-scale seismic hazard analyses with the U.S. National Seismic Hazard Model: Seismological Research Letters, v. 89, no. 3, p. 967-970, accessed April 16, 2018, at https://doi.org/10.1785/0220170261.

Ohno, I., Harada, K., and Yoshitomi, C., 2006, Temperature variation of elastic constants of quartz across the $\alpha-\beta$ transition: Physics and Chemistry of Minerals, v. 33, no. 1-9. [Also available at https://link.springer.com/article/10.1007/s00269-005-0008-3.]

Petersen, M.D., Moschetti, M.P., Powers, P.M., Mueller, C.S., Haller, K.M., Frankel, A.D., Zeng, Y., Rezaeian, S., Harmsen, S.C., Boyd, O.S., Field, N., Chen, R., Rukstales, K.S., Luco, N., Wheeler, R.L., Williams, R.A., and Olsen, A.H., 2015, The 2014 United States national seismic hazard model: Earthquake Spectra, v. 31, no. S1, p. S1-S30, accessed December 22, 2017, at https://doi.org/10.1193/120814EQS210M.

Prasad, M., Kopycinski, M., Rabe, U., and Arnold, W., 2002, Measurement of Young's modulus of clay minerals using atomic force acoustic microscopy: Geophysical Research Letters, v. 29, no. 8, p. 13-1 to 13-4. [Also available at https://doi.org/10.1029/2001GL014054.]

Reynard, B., Hilairet, N., Balan, E., and Lazzeri, M., 2007, Elasticity of serpentines and extensive serpentinization in subduction zones: Geophysical Research Letters, v. 34, no. L13307, 5 p. [Also available at https://doi.org/10.1029/2007GL030176.]

Russian Academy of Sciences, 2008, Crysallographic and chrystallochemical database for minerals and their structural analogies (WWW-MINCRYST): Moscow, Russian Academy of Sciences, Institute of Experimental Minerology, accessed June 12, 2017, at http://database.iem.ac.ru/mincryst.

Schofield, P.F., Knight, K.S., and Stretton, I.C., 1996, Thermal expansion of gypsum investigated by neutron powder diffraction: American Mineralogist, v. 81, p. 847-851. [Also available at https://doi.org/10.2138/am-1996-7-807.]

Schruben, P.G., Arndt, R.E., Bawiec, W.J., King, P.B., and Beikman, H.M., 1994, Geology of the conterminous United States at 1:2,500,000 Scale-A Digital Representation of the 1974 P.B. King and H.M. Beikman Map: U.S. Geological Survey Data

Series 11. [Data may be downloaded from https://mrdata.usgs.gov/metadata/dds-11.faq.html.]

Sheehan, A.F., de la Torre, T.L., Monsalve, G., Abers, G.A., and Hacker, B.R., 2014, Physical state of Himalayan crust and uppermost mantle - Constraints from seismic attenuation and velocity tomography: Journal of Geophysical Research, v. 119, p. 567-580. [Also available at https://doi.org/10.1002/2013JB010601.]

Shen, A.H., Bassett, W.A., and Chou, I.-M., 1993, The $\alpha-\beta$ quartz transition at high temperatures and pressures in a diamondanvil cell by laser interferometry: American Mineralogist, v. 78, p. 694-698. [Also available at http://www.minsocam.org/ ammin/AM78/AM78_694.pdf.]

Sowers, T., and Boyd, O.S., 2019, Petrologic and mineral physics database for use with the USGS National Crustal Model: U.S. Geological Survey data release, https://doi.org/10.5066/P9HN170G.

Stephenson, W.J., Reitman, N.G., and Angster, S.J., 2017, P- and S-wave velocity models incorporating the Cascadia subduction zone for 3D earthquake ground motion simulations, version 1.6-Update for Open-File Report 2007-1348: U.S. Geological Survey Open-File Report 2017-1152, 17 p., accessed September 25, 2018, at https://doi.org/10.3133/ofr20171152. [Supersedes USGS Open-File Report 2007-1348.] 
Turcotte, D.L., and Schubert, G., 1982, Geodynamics: New York, John Wiley \& Sons, 450 p.

U.S. Geological Survey, 2017, Mineral resources online spatial data (MRDS), Geologic maps of US states: U.S. Geological Survey, Mineral Resources Program, accessed on July 28, 2017, at https://mrdata.usgs.gov/geology/state/map-us.html.

Vanorio, T., Prasad, M., and Nur, A., 2003, Elastic properties of dry clay mineral aggregates, suspensions and sandstones: Geophysical Journal International, v. 155, p. 319-326. [Also available at https://doi.org/10.1046/j.1365-246X.2003.02046.x.]

Wang, Z., Wang, H., and Cates, M.E., 2001, Effective elastic properties of solid clays: Geophysics, v. 66, no. 2, p. $428-440$. [Also available at https://doi.org/10.1190/1.1444934.]

Whitaker, M.L., Liu, W., Wang, L., and Li, B., 2010, Acoustic velocities and elastic properties of Pyrite $\left(\mathrm{FeS}_{2}\right)$ to $9.6 \mathrm{GPa}$ : Journal of Earth Science, v. 21, no. 5, p. 792-800. [Also available at https://ink.springer.com/article/10.1007/s12583-010-0115-z.]

Winkler, K.W., and Nur, A., 1982, Seismic attenuation-Effects of pore fluids and frictional sliding: Geophysics, v. 47, no. 1, p. 1-15. [Also available at http://dx.doi.org/10.1190/1.1441276.]

Publishing support provided by the Science Publishing Network, Denver Publishing Service Center

For more information concerning the research in this report, contact the

Center Director, USGS Geologic Hazards Science Center

Box 25046, Mail Stop 966

Denver, CO 80225

(303) 273-8579

Or visit Geologic Hazards Science Center website at

https://www.usgs.gov/centers/geohazards 


\section{Appendix 1. Methods for Calculating Mineral Assemblages for Plutonic Igneous Rocks}

Plutonic igneous rocks are coarse grained $(>3$ [millimeters] $\mathrm{mm}$ ) and assumed to have cooled slowly (Le Maitre and others, 2002). The first step in classifying a plutonic igneous rock is to determine the percentage of the rock that is composed of mafic (M) minerals. For the purposes of this database, $\mathrm{M}$ content was determined using figure 1.1, assuming that the color index, $\mathrm{M}^{\prime}$, is a proxy for the volume percentage range for $\mathrm{M}$ content (fig. 1.1). For this explanation, we will go through the example of how the mineral assemblage for granodiorite was established.

Step 1. Determine the $M$ content based on the color index in figure 1.1. For granodiorite, it was determined that the $\mathrm{M}$ content ranges from 5-25 percent. The median $\mathrm{M}$ content for granodiorite is, therefore, 15 percent with an uncertainty of 10 percent.

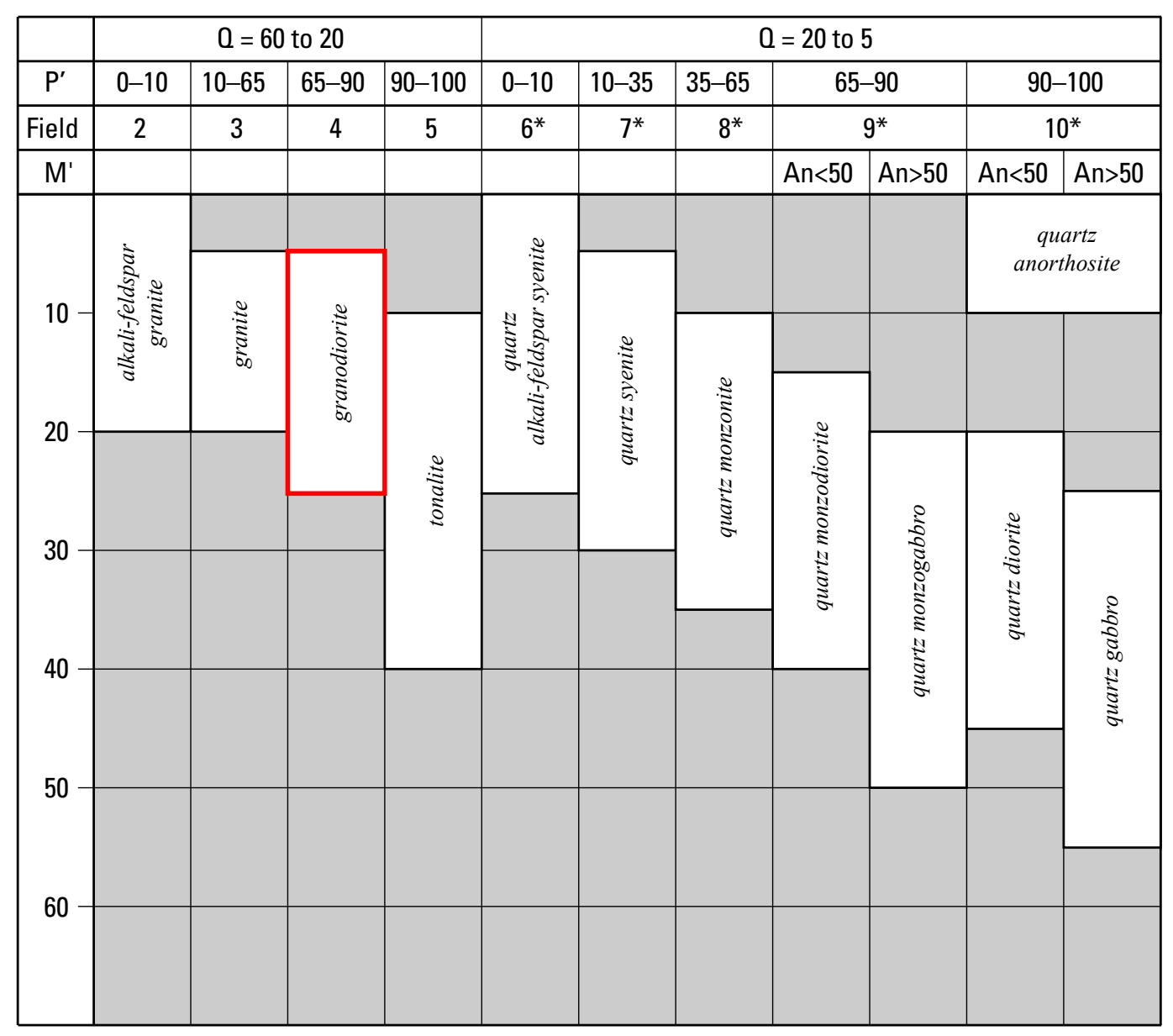

Figure 1.1. Color index for igneous rocks (adapted from Le Maitre and others, 2002). M' along the $y$-axis is the "color index," which for this study was interpreted to be approximately equal to the volume fraction of the rock that is mafic material. $P^{\prime}$ is the plagioclase ratio, and $Q$ is the volume fraction of quartz. An, anorthosite. 
Step 2. Determine the midpoint on the quartz-alkali feldspar-plagioclase-feldspathoid (QAPF) diagram (fig. 1.2). For granodiorite, the range for quartz (Q) is 20-60 percent. Therefore, the mean value for $\mathrm{Q}$ is 40 percent with a range of \pm 20 percent. From the midpoint of this field on the ternary diagram, the plagioclase $(\mathrm{P})$ value was determined to be $\sim 45$ percent with a range of about \pm 5 percent. By summing $\mathrm{Q}$ and $\mathrm{P}$ and subtracting that value from 100 , the value for alkali feldspar (A) was calculated to be $\sim 15$ percent with a range of about \pm 5 percent.

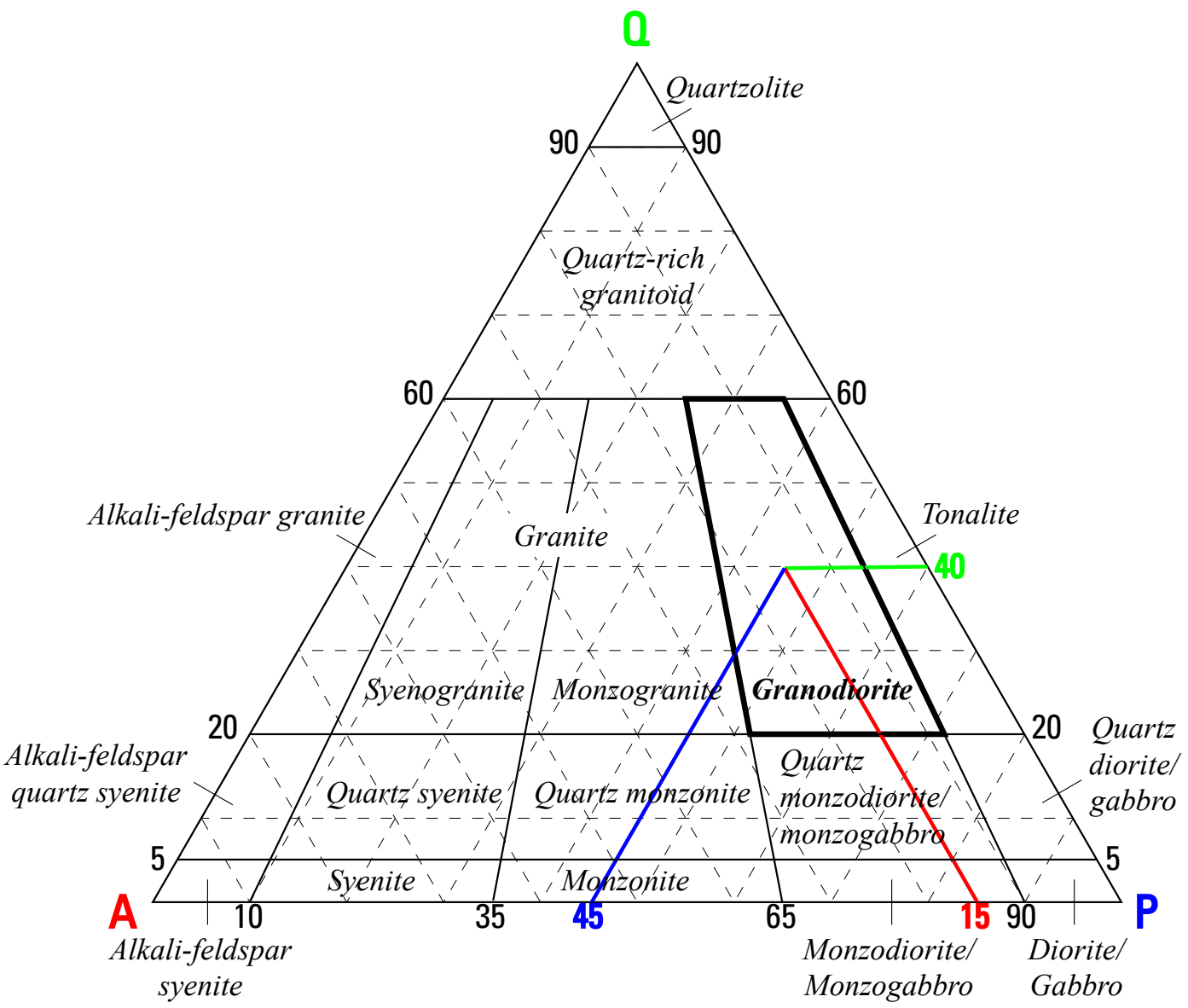

Figure 1.2. Top half of quartz-alkali feldspar-plagioclase-feldspathoid (QAPF) diagram with grid underlay to determine percentages. 0, quartz; A, alkali-feldspar; and P, plagioclase feldspar. Numbers are percentages of quartz or plagioclase feldspar. Red, blue, and green lines correspond to the example compositions given in the text. Adapted from Le Maitre and others (2002). 
Step 3. Determine the most likely mafic minerals based on Bowen's Reaction Series (fig. 1.3). If Bowen's reaction series is viewed as in figure 1.3 with increasing quartz content being present in the rock moving from olivine to quartz in the reaction series, then the most likely mafic minerals can be roughly determined by equating the approximate quartz fraction overlaid on Bowen's reaction series with the Q value from the QAPF diagram. In the instance of granodiorite with a $Q$ value of 40 percent (volume fraction of 34 percent in the rock as whole), it was determined that it would be equally likely for amphibole, biotite, and muscovite to be present. Therefore, the total mafic content (M), in this case, 15 percent, was divided equally among these three minerals.

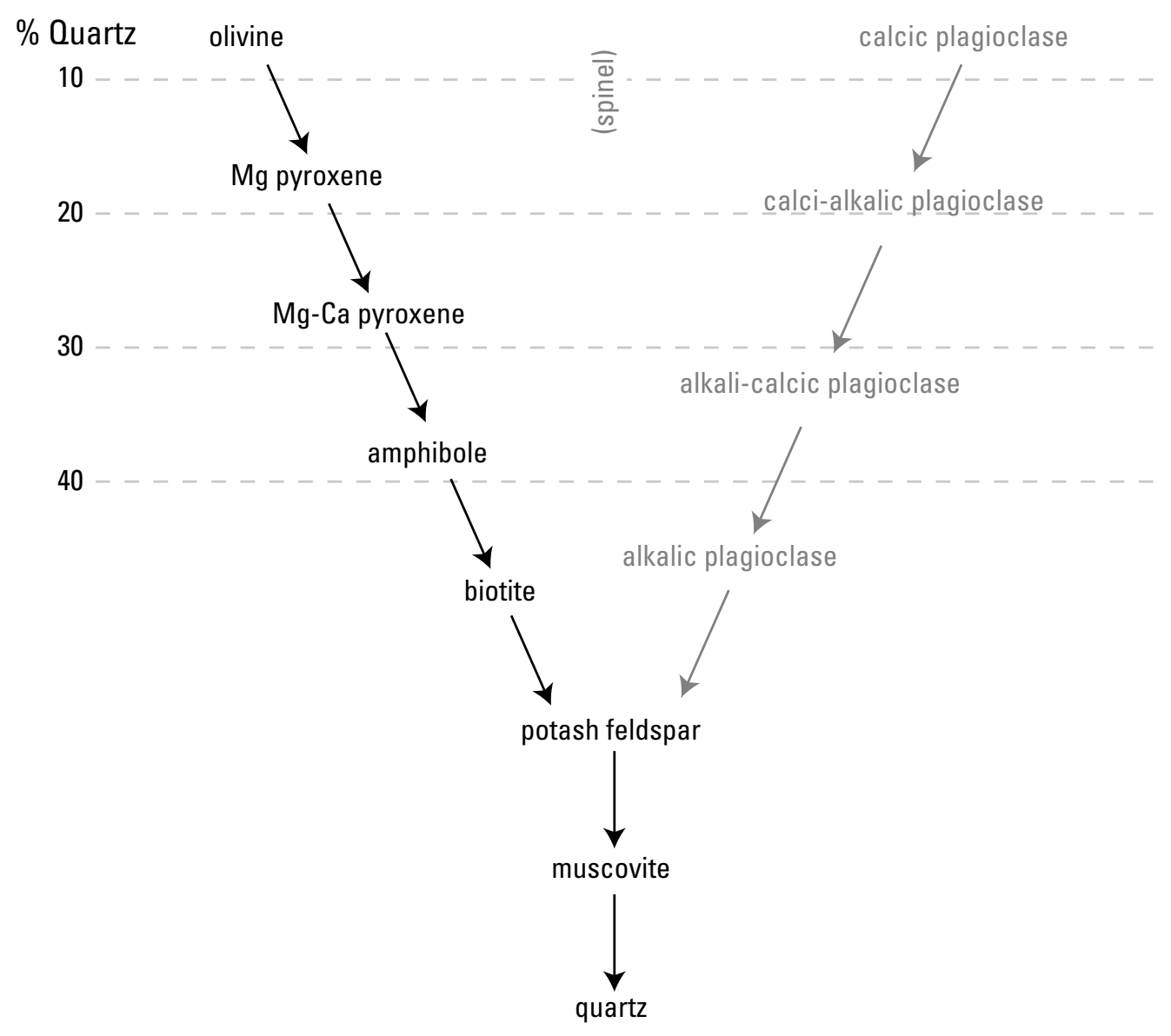

Figure 1.3. Adaptation of Bowen's Reaction Series in subalkaline rocks (Bowen, 1922) with approximate percent quartz overlay. \%, percent. 
Step 4. Renormalization of QAP values. The QAP percentages determined in step 2 are multiplied by (100-M)/100 in order for the entire mineral assemblage to sum to 100 percent (table 1.1).

Table 1.1. Common mafic minerals in igneous rocks based on percent quartz.

[Mafic minerals (indexes) are: forsterite, 12; fayalite, 13; diopside, 14; enstatite, 15; hornblende, 25; phlogopite, 27; annite,28; and muscovite,29]

\begin{tabular}{lcc}
\hline \multicolumn{1}{c}{ Rock name } & $\begin{array}{c}\text { Percent } \\
\text { composition quartz }\end{array}$ & $\begin{array}{c}\text { Mafic minerals present } \\
\text { (index) }\end{array}$ \\
\hline Alkali feldspar granite & 36 & $27,28,29$ \\
Alkali feldspar syenite & 2.185 & $25,27,28,29$ \\
Anorthosite & 2.375 & 15 \\
Diorite & 1.5625 & $14,15,25$ \\
Gabbro & 1.25 & 14 \\
Granite & 35 & $27,28,29$ \\
Granitoid & 28 & $14,15,25,27,28,29$ \\
Granodiorite & 34 & $25,27,28,29$ \\
Monzodiorite & 1.75 & $14,15,25$ \\
Monzogabbro & 1.4375 & $12,13,14,15,25$ \\
Monzonite & 1.9375 & $14,15,25$ \\
Norite & 0 & $12,15,25$ \\
Quartz diorite & 7.0875 & $14,25,27,28$ \\
Quartz gabbro & 7.5 & $12,13,14,15$ \\
Quartz monzodiorite & 8.75 & 15,25 \\
Quartz monzogabbro & 8.125 & $13,14,15,25$ \\
Quartz monzonite & 9.6875 & $14,15,25,27,28$ \\
Quartz syenite & 10.325 & $25,27,28,29$ \\
Subaluminous granite & 29.1042 & $12,13,14,15$ \\
Syenite & 1.9375 & 14,25 \\
Tonalite & 30 & $12,15,25$ \\
Troctolite & 0 & \\
\hline & & \\
\hline & & \\
\hline
\end{tabular}


